\title{
Corrigendum
}

\section{PATRE (Programme d'Amélioration Technique et de Recherche des Élevages), a programme of development for the small ruminant farmers in French Guyana - CORRIGENDUM}

\section{David Giraud-Audine and Maurice Mahieu}

doi:10.1017/S2040470010001263; published by Cambridge University Press, 8 November 2010

In the abstract by David Giraud-Audine and Maurice Mahieu (2010) presented in Advances in Animal Biosciences, the project funders were incorrect. This section should have read:

The project is funded by the European Union, the French Government and the Région Guyane

The editors apologise to the authors and readers for this mistake.

\section{Reference}

Giraud-Audine D and Mahieu M 2010. PATRE (Programme d'Amélioration Technique et de Recherche des Élevages), a programme of development for the small ruminant farmers in French Guyana. Advances in Animal Biosciences 1, 511. 